\title{
The intensity of internalization and cytotoxicity of superparamagnetic iron oxide nanoparticles with different surface modifications in human tumor and diploid lung cells
}

\author{
M. MESAROSOVA ${ }^{1}$, F. CIAMPOR ${ }^{2}$, V. ZAVISOVA 3 , M. KONERACKA ${ }^{3}$, M. URSINYOVA ${ }^{4}$, K. KOZICS ${ }^{1}$, N. TOMASOVICOVA ${ }^{3}$, A. HASHIM ${ }^{3}$, I. \\ VAVRA $^{5}$, Z. KRIZANOVA ${ }^{5}$, Z. HUSEKOVA ${ }^{4}$, M. KUBOVCIKOVA ${ }^{3}$, P. KOPCANSKY ${ }^{3}$, M. TIMKO ${ }^{3}$, A. GABELOVA ${ }^{1, *}$
}

${ }^{1}$ Cancer Research Institute, SAS, Vlárska 7, 83391 Bratislava, Slovakia; ${ }^{2}$ Institute of Virology, SAS, Dúbravská cesta 9, 84505 Bratislava, Slovakia; ${ }^{3}$ Institute of Experimental Physics, SAS, Watsonova 47, 04001 Košice, Slovakia; ${ }^{4}$ Slovak Medical University, Limbová 12,83303 Bratislava, Slovakia; ${ }^{5}$ Institute of Electrical Engineering, SAS, Dúbravská cesta 9, 84104 Bratislava, Slovakia

Correspondence: alena.gabelova@savba.sk

Received February 19, 2012 / Accepted April 17, 2012

\begin{abstract}
The human lung adenocarcinoma epithelial (A549) cells and the human embryo lung (HEL 12469) cells were used to investigate the uptake and cytotoxicity of magnetite nanoparticles (MNPs) with different chemically modified surfaces. MNPs uptake was an energy-dependent process substantially affected by the serum concentration in the culture medium. Internalized MNPs localized in vesicle-bound aggregates were observed in the cytoplasm, none in the nucleus or in mitochondria. All MNPs induced a dose- and time-dependent increase in cytotoxicity in both human lung cell lines. The cytotoxicity of MNPs increased proportionally with the particle size. Since the cytotoxicity of MNPs was nearly identical when the doses were equalized based on particle surface area, we suppose that the particle surface area rather than the surface modifications per se underlay the cytotoxicity of MNPs. In general, higher internalized amount of MNPs was found in HEL 12469 cells compared with A549 cells. Accordingly, the viability of the human embryo lung cells was reduced more substantially than that of the adenocarcinoma lung cells. The weak MNPs uptake into A549 cells might be of biomedical relevance in cases where MNPs should be used as nanocarriers for targeted drug delivery in tumor tissue derived from alveolar epithelial cells.
\end{abstract}

Key words: magnetite nanoparticles, surface modifications, cellular uptake, cytotoxicity

Over the last decades magnetite nanoparticles $\left(\mathrm{Fe}_{3} \mathrm{O}_{4}\right.$, MNPs) have attracted attention in biomedical research aimed at the improvement of diagnosis and treatment of cancer. A great effort has been focused on MNPs as magnetic resonance imaging contrast agents [1], heating mediators in hyperthermia cancer therapy [2] or as nanovectors for targeted delivery of drugs/genes into malignant tissues [3,4]. MNPs are physiologically well tolerated because iron is an essential nutrient for almost all life forms. Moreover, the superparamagnetic properties of MNPs are eligible for delivery of the drug-loaded MNPs in the target site via an external magnetic field $[5,6]$. Nowadays, MNPs are the only magnetic nanoparticles approved for biomedical application and in reality utilized.

To prevent MNPs aggregation, the surface of nanoparticles has to be modified (coated) with various surfactants, metals or natural and synthetic polymers [7-9]. Coating increases the colloidal stability of nanoparticles, the blood circulation half-life, biocompatibility, and internalization efficiency and decreases the toxicity of particles. Moreover, coating allows loading of specific ligands, antibodies, peptides, drugs and genes on the surface of particles. Functionalization of particles offers an exciting tool to make MNPs target-specific and increase their therapeutic benefit [10]. A successful delivery of magnetic nanoparticle-loaded drugs in the liver [11, 12], brain [13], ovarian [11] or in the lung [14] cancer has been already reported.

Although MNPs have been widely used in biomedical research, only limited number of studies evaluated the intensity of uptake and toxicity of nanoparticles in both the human tumor cells and their healthy (non-tumor) counterparts. To overcome this gap in our knowledge, two human lung cell lines, A549 and HEL 12469 were used to investigate the internalization and cytotoxicity of MNPs with different surface modifications commonly used in biomedical research. The 
human lung adenocarcinoma epithelial cell line A549 is a valuable in vitro model of human alveolar epithelial type 2 cells [15]. This cell line has been widely utilized in the studies of alveolar epithelium function [16] and drug delivery via the lung route [17]. The HEL 12469 cells are human diploid (embryo) lung fibroblasts; these cells were used as a model of normal (healthy) tissue. We selected the human pulmonary cells because the lungs are the target organ by both occupational and public exposure to nanoparticles [18] and the inhalation therapy is a prospective non-invasive curative modality of lung cancer and other lung illnesses [14, 19]. Inhalation therapy offers several advantages over systemic treatment. It allows delivery of high drug concentrations directly to the disease site, reduces the risk of systemic side-effects, and avoids the first-pass metabolism of the drug in the liver [20].

In our study, MNPs with different chemically modified surfaces were prepared; sodium oleate coated MNPs (SO$\mathrm{Fe}_{3} \mathrm{O}_{4}$ ), sodium oleate and polyethylene glycol coated MNPs (SO-PEG- $\mathrm{Fe}_{3} \mathrm{O}_{4}$ ) and sodium oleate, polyethylene glycol and poly(lactide-co-glycolic acid) coated MNPs (SO-PEG-PLGA$\mathrm{Fe}_{3} \mathrm{O}_{4}$ ). All MNPs were characterized in-depth by various physicochemical methods. The aim of this study was firstly to investigate the impact of surface coating on MNPs uptake into human lung cancer $v s$. diploid cells, and secondly, to evaluate the cytotoxic potential of individual surface-coated MNPs in particular in lung cell line. To reach these goals, transmission electron microscopy (TEM), Prussian blue staining and atomic absorption spectrometry (AAS) were used to visualize and quantify the amount of internalized coated MNPs in particular human lung cells and several colorimetric viability assays (MTT, LDH, trypan blue exclusion test) were applied to determinate MNPs cytotoxicity and to calculate the $\mathrm{IC}_{50}$ values.

\section{Materials and methods}

Chemicals. 3-(4,5-Dimethyl thiazol-2-yl)-2,5-diphenyl tetrazolium bromide (MTT, CAS No. 298-93-1), potassium hexacyanoferrate(II) trihydrate (C6FeK4N6.3H2O, CAS No. 14459-95-1), neutral red, poly(lactide-co-glycolic acid) (PLGA, D, L-lactide to glycolide ratio $85: 15, \mathrm{Mw}=50-75 \mathrm{kDa})$, Pluronic F68 and poly(ethylene glycol) (PEG, $1 \mathrm{kDa}, \mathrm{Mw}=1000)$ were purchased from Sigma-Aldrich (Lambda Life, Slovakia), sodium oleate was obtained from Riedel-de Haën (Hannover, Germany), glutaraldehyde ( $25 \%$ solution in water) from Serva Electrophoresis (BioTech, Slovakia), ruthenium red (SigmaAldrich, USA), white embedding media from Polyscience (Warrington, UK), acrylic resin LR White from London Resin Comp., Ltd., (UK), nitric acid (65\%, suprapur) from Merck (Slovakia), standard Fe solution from Laboratory FSA Supplies (Loughborough, UK), culture media, fetal calf serum (FCS), Trypan Blue Stain $(0.4 \%)$ and other chemicals used for cell cultivation from GIBCO (KRD Ltd., Slovakia) and the cytotoxicity detection kit LDH from Roche (Slovakia). All other chemicals and solvents were of analytical grade.
Preparation of the surface-modified magnetite nanoparticles. The magnetic iron oxide $\left(\mathrm{Fe}_{3} \mathrm{O}_{4}\right)$ nanoparticles were synthetized by a chemical co-precipitation of ferric and ferrous salts in alkali aqueous medium [21]. The colloidal suspension was stabilized by the formation of a bilayer of the surfactant, sodium oleate $\left(\mathrm{SO}, \mathrm{C}_{17} \mathrm{H}_{33} \mathrm{COONa}\right.$; the ratio $\mathrm{SO}: \mathrm{Fe}_{3} \mathrm{O}_{4}$ was 1.1:1.5). These nanoparticles are referred to as $\mathrm{SO}-\mathrm{Fe}_{3} \mathrm{O}_{4}$ in all experiments.

The nanoparticles SO-PEG- $\mathrm{Fe}_{3} \mathrm{O}_{4}$ were prepared by conjugation of poly(ethylene glycol) (PEG) to $\mathrm{SO}-\mathrm{Fe}_{3} \mathrm{O}_{4}$ particles according to the process described by Závišová et al. [22].

The magnetic nanospheres SO-PEG-PLGA- $\mathrm{Fe}_{3} \mathrm{O}_{4}$ were prepared according to Fessi et al. [23] with some modifications [24]. In brief, $100 \mathrm{mg}$ of poly(lactide-co-glycolic acid) (PLGA) was dissolved in $10 \mathrm{ml}$ of acetone (the organic phase) and the nanoparticles SO-PEG- $\mathrm{Fe}_{3} \mathrm{O}_{4}\left(83 \mathrm{mg} \mathrm{Fe} \mathrm{O}_{4} / \mathrm{ml}\right)$ were mixed with the nonionic detergent, Pluronic F68 $(3.2 \mathrm{mg} / \mathrm{ml}$ ) (the aqueous colloid). Then, the organic phase was added drop wise into the aqueous colloid and stirred vigorously for several hours to allow complete evaporation of the organic solvent at room temperature. Aggregates were removed by filtration through $0.3 \mu \mathrm{m}$ filter.

The coupling of sodium oleate and polymers (PEG, PLGA) on magnetite nanoparticles was verify by infrared (IR) spectrometry.

Characterization of the surface-coated magnetite nanoparticles. The crystallographic structure of prepared magnetic iron oxide nanoparticles was determined by X-ray diffraction (XRD) measurement using a Philips X'Pert Pro diffractometer equipped with a $\mathrm{Cu} K a$ source $(\lambda=0.154056 \mathrm{~nm})$. The morphology of SO- $\mathrm{Fe}_{3} \mathrm{O}_{4}$, SO-PEG- $\mathrm{Fe}_{3} \mathrm{O}_{4}$ and SO-PEG-PLGA$\mathrm{Fe}_{3} \mathrm{O}_{4}$ nanoparticles was investigated by transmission electron microscopy (TEM) using a Tesla BS 500 microscope operated at $90 \mathrm{kV}$ and scanning electron microscopy (SEM) at a JEOL $7000 \mathrm{~F}$ microscope at $10 \mathrm{kV}$. The particle size distribution in particular magnetic fluid (colloidal solution of nanoparticles) was performed by photon cross correlation spectroscopy (PCCS, Nanophox, Sympatec GmbH, Germany). The magnetic properties of magnetic fluids were characterized by superconducting quantum interference device (SQUID) magnetometer (Quantum Design, USA) at room temperature and the zeta potential $(\zeta)$ at Zetasizer Nano ZS by Malvern Instruments, UK. The Fe concentration in particular magnetic fluids was determined by the atomic absorption spectroscopy (AAS) using AA240FS fy. Variant or by inductively coupled plasma mass spectrometry (ICP-MS) using XSeries 2 fy. Thermo Scientific.

Cell cultures. The human lung adenocarcinoma epithelial cell line A549 was maintained in Dulbecco's modified Eagle medium (DMEM) supplemented with $10 \%$ fetal calf serum (FCS) and antibiotics (penicillin $100 \mathrm{U} / \mathrm{ml}$; streptomycin and kanamycin $100 \mu \mathrm{g} / \mathrm{ml}$ ). The human embryo lung cells, HEL 12469, were cultivated in Eagle's Minimum Essential Medium (MEM) supplemented with $10 \%$ fetal calf serum (FCS), $1 \%$ non-essential amino acids and antibiotics (penicillin 50 
$\mathrm{U} / \mathrm{ml}$; streptomycin $50 \mu \mathrm{g} / \mathrm{ml}$ ). Cell lines were cultured in a humidified atmosphere of $5 \% \mathrm{CO}_{2}$ at $37^{\circ} \mathrm{C}$. In experiments focused on MNPs uptake and cytotoxicity, A549 and HEL 12469 were exposed to nanoparticles in medium supplemented with $2 \%$ FCS.

Treatment of cells. Exponentially growing cells were exposed to different concentrations of $\mathrm{SO}-\mathrm{Fe}_{3} \mathrm{O}_{4}, \mathrm{SO}-\mathrm{PEG}-\mathrm{Fe}_{3} \mathrm{O}_{4}$ and SO-PEG-PLGA- $\mathrm{Fe}_{3} \mathrm{O}_{4}$ nanoparticles for $4 \mathrm{~h}$ and $24 \mathrm{~h}$. In the preliminary experiments the cytotoxicity of the surfactant, sodium oleate (SO), and the polymer, PEG, as well as a binary mixture of $\mathrm{SO}+\mathrm{PEG}$ was measured. The SO:PEG ratio in the binary mixture was 14:1 based on the actual SO and PEG concentrations determined on the SO-PEG- $\mathrm{Fe}_{3} \mathrm{O}_{4}$ nanoparticles. The doses applied to human lung cells were expressed as $\mathrm{mmol} / \mathrm{L}$ of iron oxide. Under this condition, equal numbers of MNPs were applied to the human lung cells. At the end of treatment, cells were washed with PBS and either processed immediately or post-cultivated in fresh medium for various time intervals ( $24 \mathrm{~h}$ and $48 \mathrm{~h}$ ) and then processed. In a time course study focused on the rate of nanoparticle uptake, cells were treated for different time intervals ( $1 \mathrm{~min}, 5 \mathrm{~min}, 15 \mathrm{~min}$, $30 \mathrm{~min}$, and $24 \mathrm{~h}$ ). The clearance of nanoparticles was analyzed after $24 \mathrm{~h}$ and $48 \mathrm{~h}$ of post-cultivation in fresh medium.

Cytotoxicity of magnetite surface-coated nanoparticles.

MTT assay. The 3-(4,5-dimethyl thiazol-2-yl)-2,5-diphenyl tetrazolium bromide (MTT) assay based on the protocol desribed by Mosmann [25] was used with minor modifications. In brief, viability of A549 and HEL 12469 cells was carried out in plastic 96 -well cell culture cluster plates at $4 \times 10^{3}$ cells/well (A549 cells) or $2.5 \times 10^{4}$ cells/well (HEL 12469 cells) and the absorbance measured by photometric evaluation (at 540 $\mathrm{nm}$ excitation and $690 \mathrm{~nm}$ emission wavelengths) using the Multiskan Multisoft plate reader (Labsystems, Finland) and Genesis software provided by the producer. IC $_{50}$ values were calculated from the dose-response curves using CalcuSyn software (Biosoft, Cambridge, UK). The color of magnetic nanoparticles is dark brown and interferes with the spectrophotometry readings when MNPs are taken up by the cells. Therefore the net readings were corrected with a net particle reading according to Hafeli et al. [26].

LDH release assay. Cytotoxicity induced by MNPs was assessed also by lactate dehydrogenase (LDH) leakage into the culture medium. A549 cells were plated on plastic 96-well cell culture cluster plates at $4 \times 10^{3}$ cells/well. Following exposure to MNPs the plate was centrifuged at $250 \mathrm{x} g$ for $5 \mathrm{~min}$ and the culture medium was aspirated in order to obtain a cell free supernatant. The activity of $\mathrm{LDH}$ in the medium was determined using a commercially available kit from Roche (Slovakia). Aliquots of media, mixture of catalyst and dye reagent were mixed in a 96-well plate and incubated $15 \mathrm{~min}$ in the dark by the room temperature. Then the stop solution was added, the plate was mixed for $10 \mathrm{~s}$. and the absorbance measured (at $492 \mathrm{~nm}$ excitation and $690 \mathrm{~nm}$ emission wavelengths) using the Multiskan Multisoft plate reader (Labsystems, Finland) and Genesis software provided by the producer. Results were presented as percentage of control values. To enhance MNPs ablation from the culture medium, the plates were put on the magnets after centrifugation. Despite this modification, MNPs persist in the medium and were shown to interfere with LDH determination.

Trypan blue exclusion test. The dye exclusion test was used to determine the number of viable cells present in a cell suspension after exposure to MNPs. The live cells possess intact cell membranes that exclude trypan blue dye, whereas dead cells do not. The suspension of treated and control cells was mixed with dye ( $0.4 \%$ trypan blue) and then visually examined to determine the blue cells (take up dye) and clear cells (exclude dye). An aliquot of the cell suspension was taken in a hemocytometer, observed under phase contrast microscope and cell viability was determined. The percentage viability was calculated by dividing the number of viable cells by the total number of cells and multiplied by 100 .

Transmission electron microscopy (TEM). The MNPs uptake and accumulation in human lung cells (A549 and HEL 12469) was evaluated by TEM. Cells were plated on Petri dishes (Ø $60 \mathrm{~mm}, 3-5 \times 10^{5}$ cells/dish) and exposed to surface-coated magnetite nanoparticles at exponential phase of growth. After treatment, cells were washed twice with PBS (phosphate buffer saline) and fixed with $2.5 \%$ glutaraldehyde in PBS buffer ( $\mathrm{pH}$ 7.2) for $30 \mathrm{~min}$ at room temperature. Then cells were dehydrated in a graded series of alcohol $(30,50$, $70,100 \%$ twice; 5 min each step), transferred into a mixture of the resin LR White and pure alcohol (v/v 1:1) for $30 \mathrm{~min}$, followed by the incubation with pure resin for another $30 \mathrm{~min}$. or overnight. Cells were then scraped from the dishes with a rubber policeman and transferred into an embedding tubes filled with resin and let polymerized at $61^{\circ} \mathrm{C}$ for $24 \mathrm{~h}$. Next day, ultra-thin sections were cut with a diamond knife, floated on water and mounted on copper grids without any supporting film and stained with $2 \%$ uranyl acetate in distilled water for $30 \mathrm{~min}$. Sections were analyzed by electron microscopes JEOL EX at $100 \mathrm{kV}$ and JEOL $2200 \mathrm{FS}$ at $200 \mathrm{kV}$ with EELS analyses (electron energy loss spectroscopy). When ruthenium red was used to detect the ultrastructure of the surface layer of A549 and HEL 12469 cells, the dye was added to the fixative at a concentration of $50 \mathrm{mg} / 100 \mathrm{ml}$ and fixation was prolonged to 1 hour.

Prussian blue staining. The human lung cells were plated on Petri dishes ( $600 \mathrm{~mm}, 3-6 \times 10^{5}$ cells per dish) and exposed to surface-coated MNPs. After treatment cells were fixed with $4 \%$ paraformaldehyde solution for $15 \mathrm{~min}$ and then washed twice with PBS buffer, followed by incubation in perl's solution (equal parts of $6 \%$ hydrochloric acid and $2 \%$ potassium ferrocyanide) for $30 \mathrm{~min}$ and washed with deionized water. Then they were counterstained with $0.5 \%$ Neutral red solution for $3 \mathrm{~min}$, washed and let dry. Cells were examined under a light microscope.

Quantification of the internalized amount of coated magnetite nanoparticles. Atomic absorption spectrometry (AAS) was adapted to quantify the MNPs uptake into cells. 
Analyses of all samples in duplicate were carried out by flame atomic absorption spectrometry for Fe. The digestion of scraped cells was realized with $\mathrm{HNO}_{3}(500 \mu \mathrm{l})$ in ultrasonic bath at $85^{\circ} \mathrm{C}$ for $2 \mathrm{~h}$. The digests were then diluted with $2 \%$ $\mathrm{HNO}_{3}$ in deionised water. The instrumental parameters for $\mathrm{Fe}$ determination were: wavelength $248.3 \mathrm{~nm}$, slit width $0.2 \mathrm{~nm}$, flame type: acetylene-air, flow: $2.0 \mathrm{~L} / \mathrm{min}$ for acetylene and $13.5 \mathrm{~L} / \mathrm{min}$ for air, deuterium background correction, method of calibration curve in the range $0.1-10 \mathrm{mg} / \mathrm{L}$. The limit of detection (LOD) and limit of quantification (LOQ) for the AAS instrument were $0.0015 \mathrm{mg} / \mathrm{L}$ and $0.0049 \mathrm{mg} / \mathrm{L}$, respectively. LOD and LOQ for the AAS method were $0.0074 \mathrm{mg} / \mathrm{L}$ and $0.0245 \mathrm{mg} / \mathrm{L}$, respectively. In case of low Fe concentrations in samples and small sample volume, the ICP-MS method with collision cell technology was used.

Fourier transformed infrared (FTIR) spectral studies. The FTIR spectroscopy was used to confirm the adsorption of sodium oleate, PEG and PLGA on the surface of magnetite nanoparticles and to characterize the immobilization of serum component(s) on the magnetic nanoparticle surface. The FTIR spectra were obtained using the Fourier Transform Infrared spectrometer FTLA2000 instrument (ABB, resolution $4 \sim \mathrm{cm}^{-1}$ ) by Attenuated Total Reflectance measurements with diamond or ZnSe window. Before measurement all samples were lyophilized.

Statistical analysis. Data are given as mean values with \pm SD. The differences between control cells and treated cells were evaluated by the Student's $t$-test. The threshold of statistical significance was set at $\mathrm{p}<0.05$.

\section{Results}

Characterization of the surface-coated magnetic nanoparticles. The X-ray diffraction measurement confirmed the magnetite inner core with a mean diameter $7.6 \mathrm{~nm}$ in all magnetic surface-coated nanoparticles (data not shown). The TEM and SEM analyses determined nearly spherical shape with a primarily smooth surface of all particles. Representative images of SO-PEG- $\mathrm{Fe}_{3} \mathrm{O}_{4}$ are shown in Figure 1. The parameters of individual MNPs are shown in Table 1. The hydrodynamic size of nanoparticles increased proportionally with the surface coating. The FTIR spectra proved the immobilization of SO, PEG and PLGA on the magnetite inner core (data not shown). The magnetic measurements confirmed

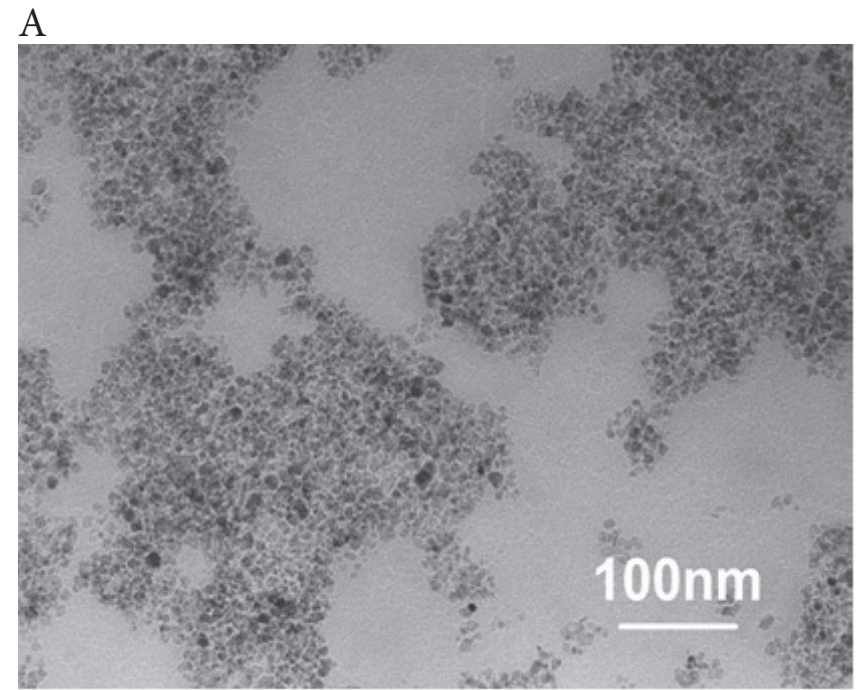

\section{B}

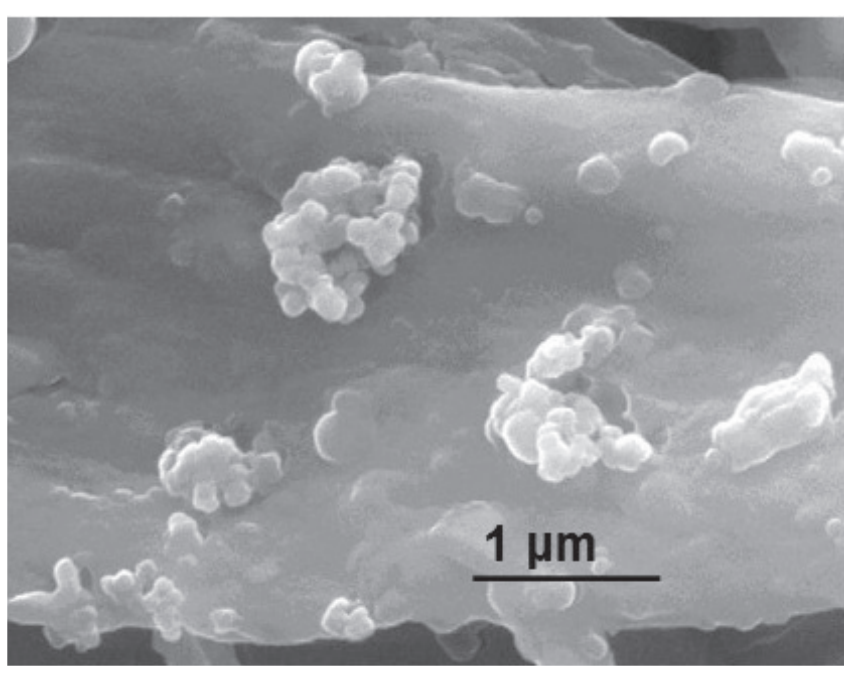

Figure 1. Representative TEM (A) and SEM (B) images of SO-PEG-Fe $\mathrm{O}_{4}$.

the superparamagnetic behavior of all magnetic fluids at room temperature with blocking temperature at $295 \mathrm{~K}$. The zeta potential values proved the stability of prepared magnetic fluids. The concentrations of $\mathrm{Fe}_{3} \mathrm{O}_{4}$ in particular magnetic fluids

Table 1. Characteristics of magnetite nanoparticles with different surface modifications.

\begin{tabular}{lcc}
\hline & SO-Fe $_{3} \mathrm{O}_{4}$ & SO-PEG-Fe $_{3} \mathrm{O}_{4}$ \\
\hline Particle size $\left(\mathrm{D}_{\mathrm{H}}\right)$ & $44 \mathrm{~nm}$ & $76 \mathrm{~nm}$ \\
$\mathrm{I}_{\mathrm{s}}$ at $295 \mathrm{~K}$ & $7.7 \mathrm{Am}^{2} \mathrm{~kg}^{-1}$ & $6.0 \mathrm{Am}^{2} \mathrm{~kg}^{-1}$ \\
Zeta potential $(\zeta)$ & $-41.8 \mathrm{mV}$ & $-42.3 \mathrm{mV}$ \\
$\mathrm{Fe}_{3} \mathrm{O}_{4}$ concentration & $134 \mathrm{mg} / \mathrm{ml} \mathrm{nm}$ & $0.88 \mathrm{Am}^{2} \mathrm{~kg}^{-1}$ \\
The surface area per iron oxide particle & $6.079 \times 10^{-11} \mathrm{~cm}^{2}$ & $-50 \mathrm{mV}$ \\
The number of iron oxide particles per $\mathrm{ml}$ & $1.13 \times 10^{17}$ & $13.7 \mathrm{mg} / \mathrm{ml} / \mathrm{ml}$ \\
\hline
\end{tabular}



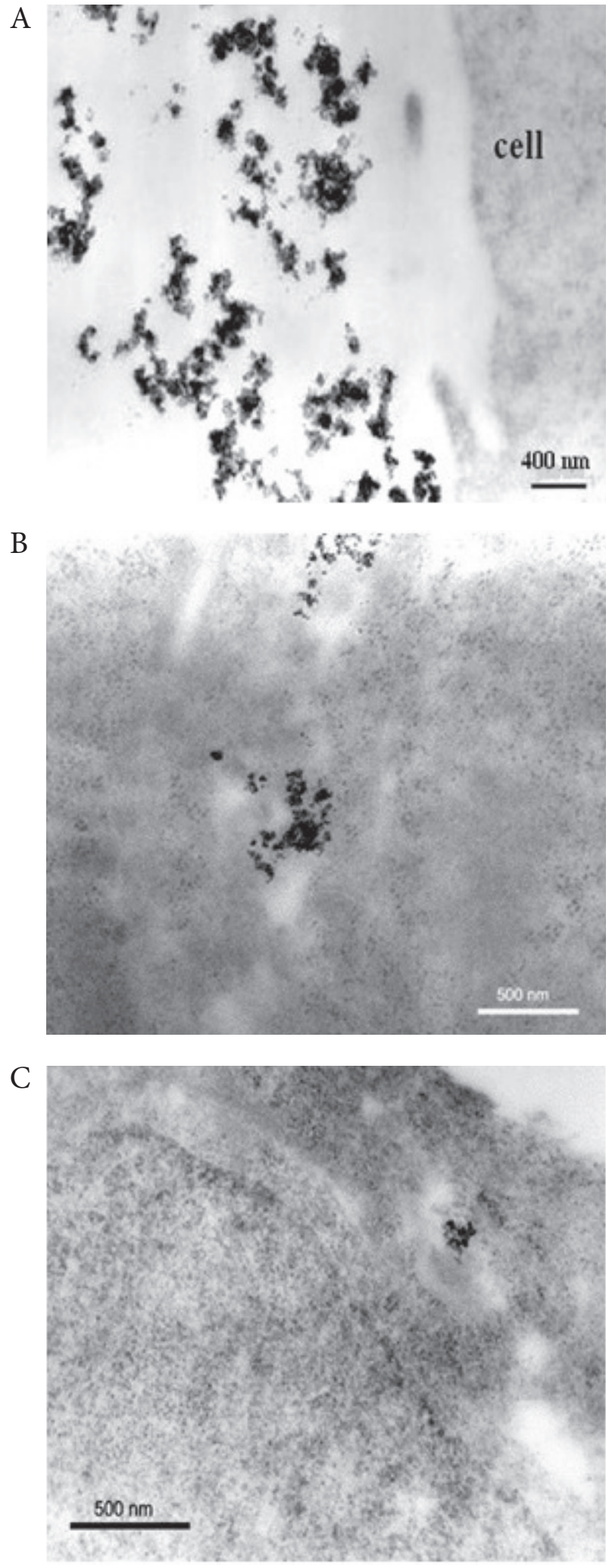

Figure 2. The impact of fetal calf serum (FCS) on nanoparticle uptake. TEM images of A549 cells exposed to $0.3 \mathrm{mM}$ SO-PEG-Fe $\mathrm{O}_{4}$ for $24 \mathrm{~h}$ in serum-free culture medium (A), in medium supplemented with $2 \%$ FCS (B) and $10 \%$ FCS (C).

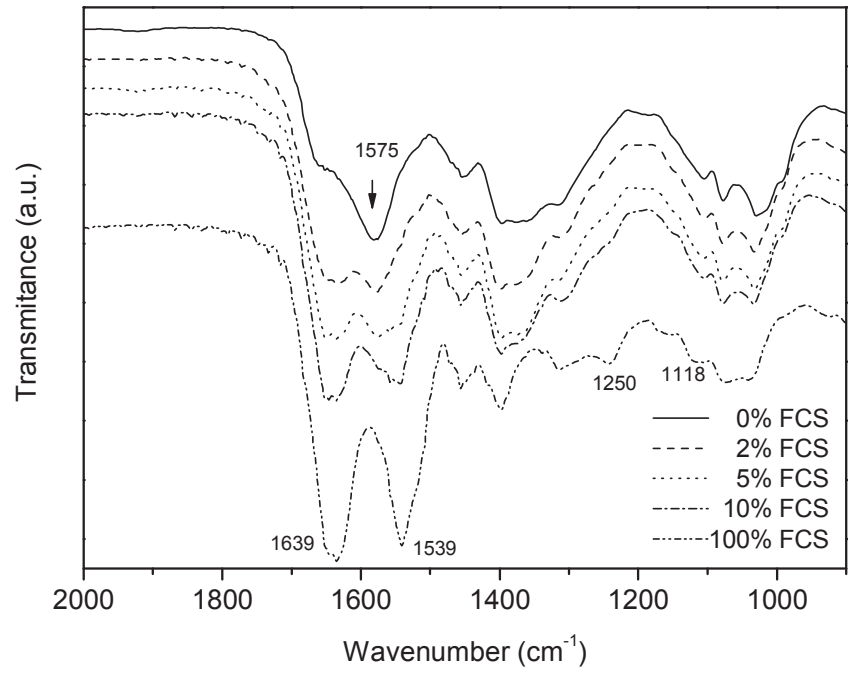

Figure 3. Infrared spectra of pure FCS (100\% FCS), and of SO-PEG-Fe $\mathrm{O}_{4}$ particles in serum-free medium ( $0 \%$ FCS) and in medium supplemented with $2 \%, 5 \%$ and $10 \%$ FCS. Spectra are shifted vertically for clarity.

were determined by atomic absorption spectrometry (AAS). The results obtained by the AAS method showed very good comparability with those determined by the ICP-MS.

Magnetite nanoparticle uptake and accumulation in the human lung cells. Preliminary experiments were aimed to optimize the treatment conditions of lung cell lines with magnetic surface-coated nanoparticles. The A549 cells were exposed to $0.3 \mathrm{mM}$ SO-PEG- $\mathrm{Fe}_{3} \mathrm{O}_{4}$ for $24 \mathrm{~h}$ in medium supplemented with different concentrations of serum $(0 \%, 2 \%$, $5 \%, 10 \%)$. The TEM results demonstrated that MNPs uptake was dependent on serum concentration in the cultured medium. No nanoparticles were found in cells treated in serum free medium; aggregates of MNPs were observed exclusively outsides the cells (Fig. 2A). Moreover, differences in the internalized amount of MNPs were found in dependence on serum concentrations in the culture medium. More MNPs were observed inside the cells at $2 \%$ fetal calf serum (FCS) (Fig. 2B) than at $10 \%$ FCS (Fig. 2C) in the cultured medium. These observations suggested that some serum component(s), most likely proteins, facilitated MNPs uptake. To prove our hypothesis the IR spectrometry was carried out. FTIR spectra of pure FCS (100\% FCS) and SO-PEG- $\mathrm{Fe}_{3} \mathrm{O}_{4}$ particles in serum free medium ( $0 \%$ FCS) and in medium supplemented with 2\%,5\% and 10\% FCS are shown in Figure 3. The absence of absorption bands observed at $1118 \mathrm{~cm}^{-1}$ and $1250 \mathrm{~cm}^{-1}$ in samples of SO-PEG- $\mathrm{Fe}_{3} \mathrm{O}_{4}$ particles in medium supplemented with $2 \%, 5 \%$ and $10 \%$ FCS compared with pure FCS $(100 \%$ FCS) confirmed coupling between some serum proteins and MNPs. Moreover, the changes in the ratio of peaks at $1639 \mathrm{~cm}^{-1}$ (100\% FCS) and at $1575 \mathrm{~cm}^{-1}$ (serum-free medium) corresponded to the differences in serum concentrations in culture medium. Furthermore, the strong absorption band at $1539 \mathrm{~cm}^{-1}$ observed in FTIR spectrum of $100 \%$ FCS was 
missing in the FTIR spectrum of SO-PEG-Fe $\mathrm{O}_{4}$ particles in medium supplemented with $2 \%$ FCS. In contrast, contribution from this peak (at $1539 \mathrm{~cm}^{-1}$ ) was observed in FTIR spectra of SO-PEG- $\mathrm{Fe}_{3} \mathrm{O}_{4}$ particles in medium supplemented with $5 \%$ and $10 \%$ FCS. These results might suggest either a limitation in the amount of serum proteins coupled with MNPs or the bound of a particular serum protein onto MNPs surface. Based on these data, all experiments dealing with the biological activity of surface coated magnetite nanoparticles were performed in medium supplemented with $2 \%$ FCS.

The spectroscopic analysis (TEM/EELS) has revealed that the clusters localized in the cytoplasm of exposed human lung cells consist of the iron (Fe) (Fig. 4A). Moreover, this analysis has argued that the surface coating of MNPs remains obviously intact after the uptake; the iron map (Fig. 4B) and the carbon map (Fig. 4C) of MNPs aggregates overlapped. In general, magnetite nanoparticles regardless the surface modifications were localized in agglomerate-bound vesicules and found exclusively in the cytoplasm but none in the nucleus or mitochondria.

Furthermore, TEM analysis has demonstrated that MNPs internalization is an energy-dependent process. Incubation of lung A549 cells at $4^{\circ} \mathrm{C}$ prior to exposure to $0.3 \mathrm{mM}$ SO-PEG$\mathrm{Fe}_{3} \mathrm{O}_{4}$ halted completely MNPs uptake (data not shown). A time course study focused on the kinetics of MNPs uptake has shown that MNPs are taken up relatively rapidly. The A549 cells were treated with $0.3 \mathrm{mM} \mathrm{SO}-\mathrm{PEG}-\mathrm{Fe}_{3} \mathrm{O}_{4}$ and the MNPs uptake was evaluated at several time intervals ( $1 \mathrm{~min}, 5 \mathrm{~min}, 15 \mathrm{~min}, 30$ min, 24h) after the treatment. MNPs aggregates were detected inside the cells after $30 \mathrm{~min}$ of cell exposure; at shorter time

A

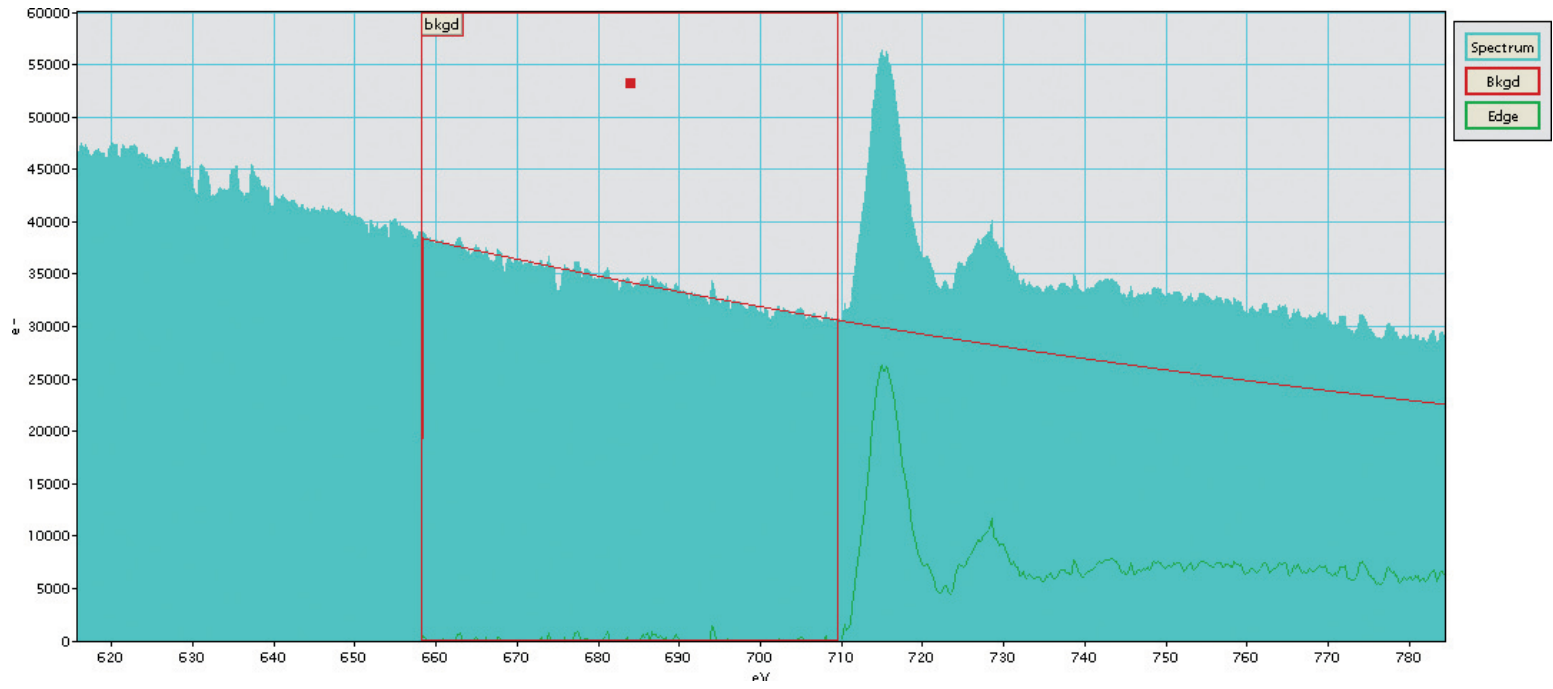

B

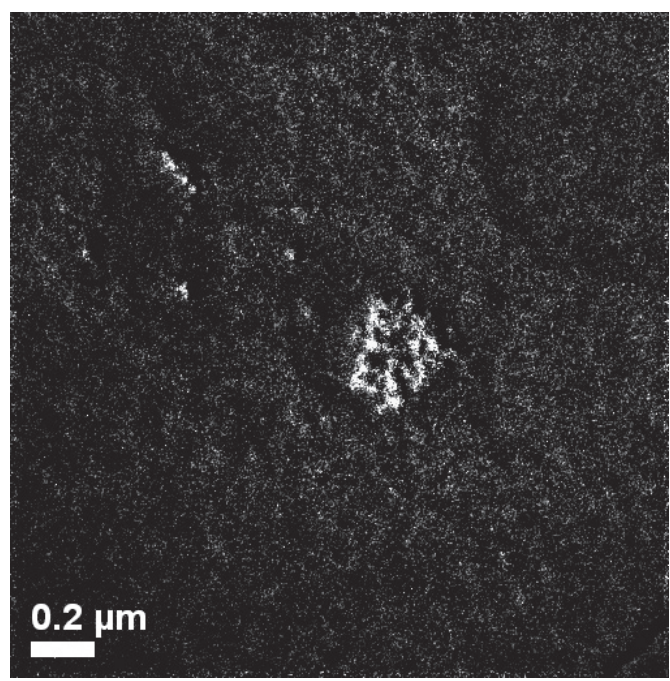

C

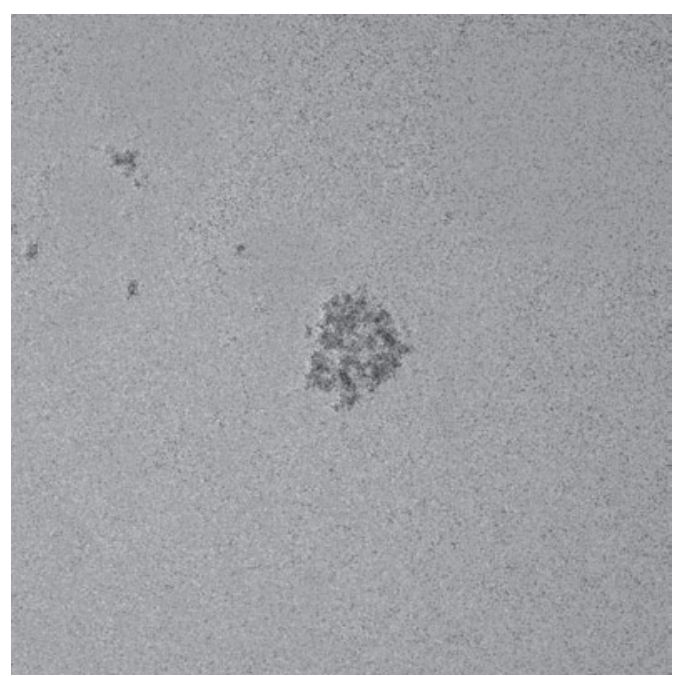

Figure 4. TEM/EELS analysis of $\mathrm{A} 549$ cells exposed to $\mathrm{SO}-\mathrm{Fe}_{3} \mathrm{O}_{4}$. A549 cells were treated with $0.3 \mathrm{mM} \mathrm{SO}-\mathrm{Fe}_{3} \mathrm{O}_{4}$ particles for $24 \mathrm{~h}$. The Fe-L SpectrumBKG (A), the iron map (B); the carbon map (C). 
A

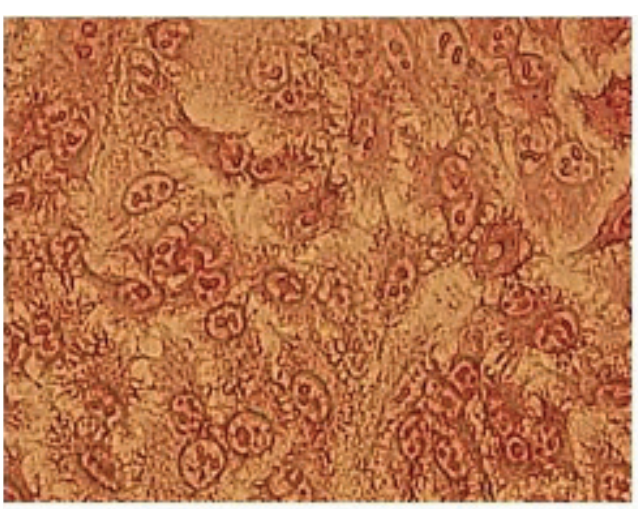

C

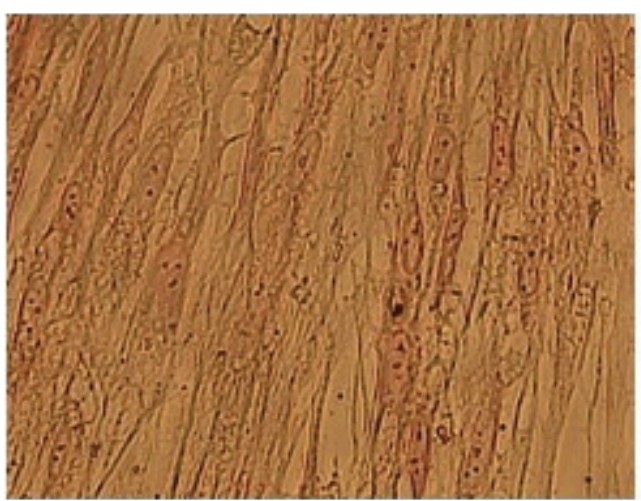

B

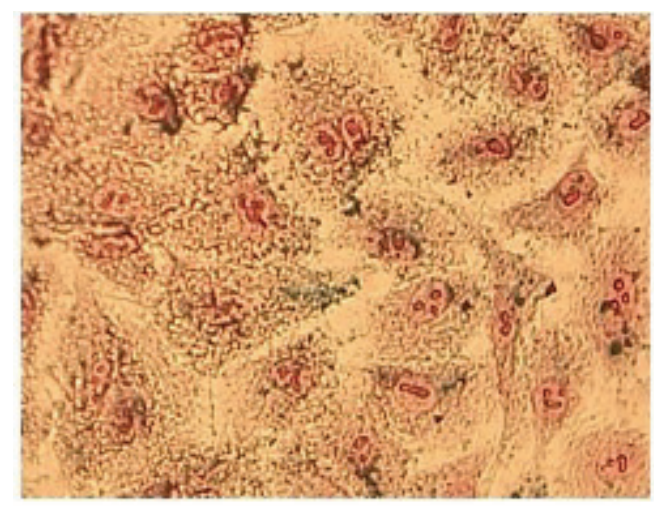

D

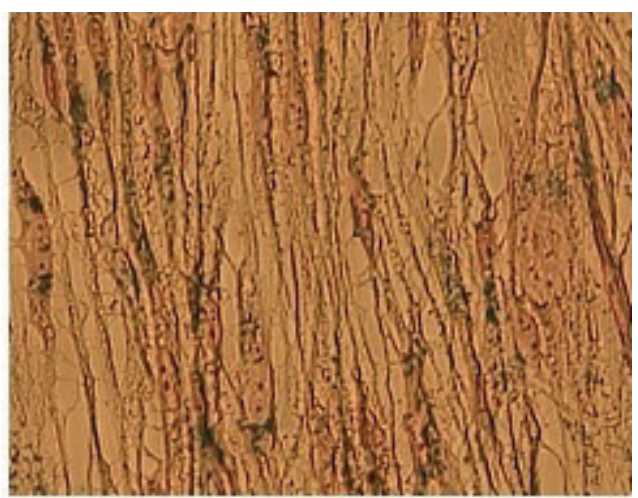

Figure 5. Images of Prussian blue stained A549 cells (A, B) and HEL 12469 cells (C, D). A549 cells were treated with 0.3mM SO-PEG-Fe $\mathrm{O}_{4}$ and HEL 12469 cells with $0.2 \mathrm{mM} \mathrm{SO}-\mathrm{PEG}-\mathrm{Fe}_{3} \mathrm{O}_{4}$ for $24 \mathrm{~h}$. The treated cells were counterstained with Neutral red solution. Control cells (A, C), treated cells (B, D). Magn. 200x.

intervals, MNPs were found adhered to the outer layer of the cell membrane, and part of them was present in the cytoplasm in the form of individual particles (data not shown).

The Prussian blue staining suggested differences between A549 and HEL 12469 cells in the intensity of internalization. While only few blue spots were observed in the cytoplasm of MNPs-exposed A549 cells (Fig. 5B), under the same treatment conditions, substantially more blue spots were found in MNPs-exposed HEL 12469 cells (Fig. 5D). To quantify the amount of internalized coated MNPs in A549 and HEL 12469 cells, the AAS analysis was adapted to determine the amount of cellular iron. The results showed that at least one order of magnitude larger amount of iron (expressed as pg Fe per cell) was detected in the human lung diploid HEL 12469 cells compared with the tumor lung A549 cells. Moreover, differences in the amount of internalized MNPs (pg Fe/cell) were also found in dependence on surface modifications. In tumor lung cells, $\mathrm{SO}-\mathrm{Fe}_{3} \mathrm{O}_{4}$ and $\mathrm{SO}-\mathrm{PEG}-\mathrm{Fe}_{3} \mathrm{O}_{4}$ particles were internalized less efficiently than SO-PEG-PLGA-Fe $\mathrm{O}_{4}$ ones (0.151 pg Fe/cell and $0.118 \mathrm{pg} \mathrm{Fe} /$ cell, respectively vs. 0.504 pg Fe/cell). In contrast, a size dependent uptake of coated
MNPs were determined in human lung diploid HEL 12469 cells ( $\mathrm{SO}-\mathrm{Fe}_{3} \mathrm{O}_{4}: 9.745 \mathrm{pg}$ Fe/cell; $\mathrm{SO}-\mathrm{PEG}-\mathrm{Fe}_{3} \mathrm{O}_{4}: 3.656 \mathrm{pg}$ $\mathrm{Fe} /$ cell; $\mathrm{SO}-\mathrm{PEG}-\mathrm{PLGA}-\mathrm{Fe}_{3} \mathrm{O}_{4}: 2.24 \mathrm{pg}$ Fe/cell).

Nanospheres (SO-PEG-PLGA-Fe $\mathrm{O}_{4}$ ) entered less efficiently the human lung diploid cells compared with human tumor lung cells. After $30 \mathrm{~min}$ of exposure, no or only very low amount of nanoparticles was attached to the outer layer of the cell membrane of A549 cells and HEL 12469, respectively (Fig. 6A, 6C). After $24 \mathrm{~h}$ of exposure, aggregates of nanospheres were observed inside A549 cells (Fig. 6B); however, under the same treatment conditions, the human diploid lung cells were heavily destroyed (Fig. 6D).

Experiments focused on MNPs clearance have revealed that MNPs elimination is a very slow process; particles are retained inside the cells over several generations. Still $48 \mathrm{~h}$ after the treatment aggregates of MNPs were observed in the cytoplasm (data not shown).

Cytotoxicity of prepared magnetic fluids, sodium oleate, PEG and SO+PEG mixture. Since the color of the magnetic fluids is dark brown and can interfere with the measurement, three common cytotoxicity detection assays, MTT, LDH and 
A

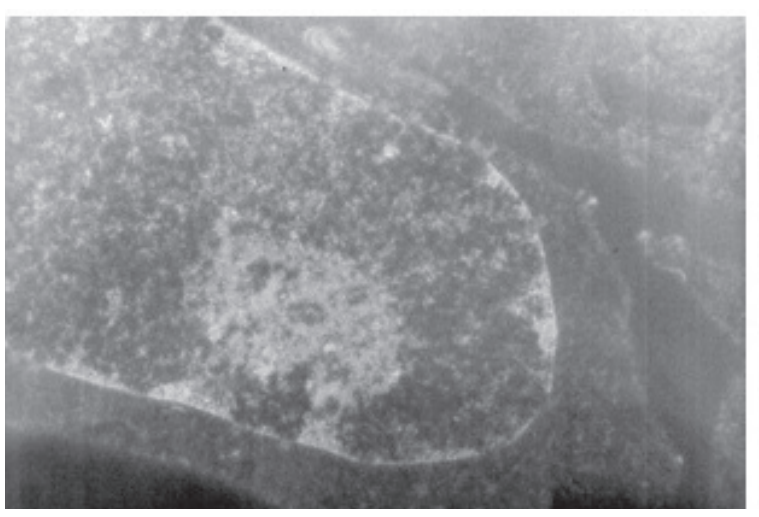

C

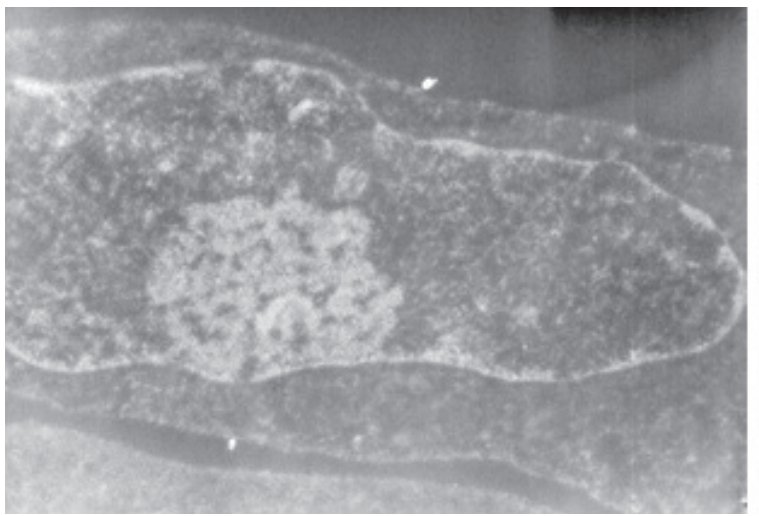

$\mathrm{B}$

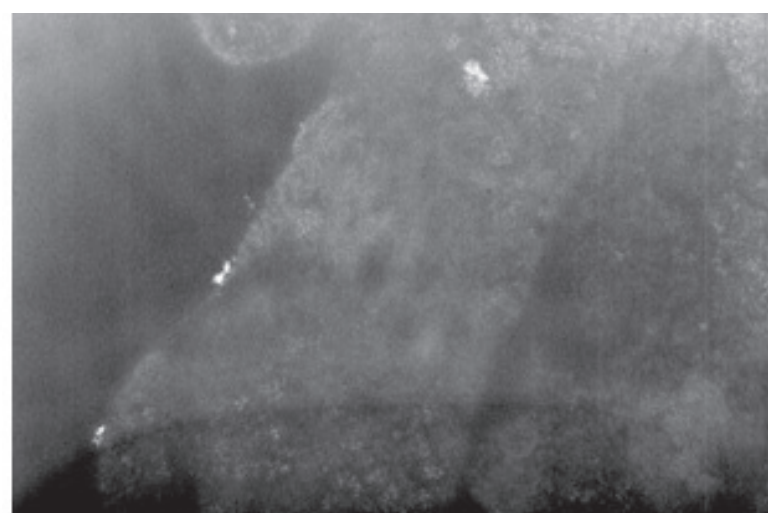

$\mathrm{D}$

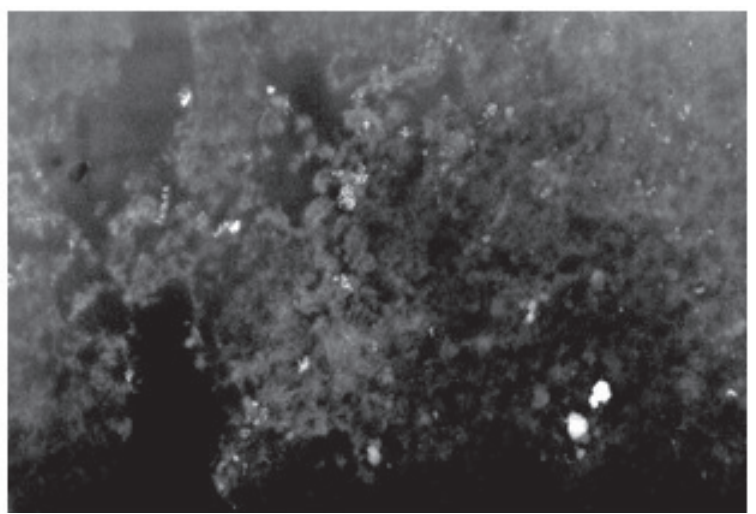

Figure 6. Uptake of SO-PEG-PLGA-Fe $\mathrm{O}_{4}$ particles into A549 (A, B) and HEL 12469 cells (C, D). Pulmonary cells were exposed to 0.2 mM SO-PEGPLGA-Fe $\mathrm{O}_{4}$ for $30 \mathrm{~min}(\mathrm{~A}, \mathrm{C})$ and for $24 \mathrm{~h}$ (B, D). Magn. $10000 \mathrm{x}(\mathrm{A}, \mathrm{C})$ and $20000 \mathrm{x}$ (B, D).

Table 2. $\mathrm{IC}_{50}$ values of magnetic fluids ( $\mathrm{SO}-\mathrm{Fe}_{3} \mathrm{O}_{4}, \mathrm{SO}-\mathrm{PEG}-\mathrm{Fe}_{3} \mathrm{O}_{4}$ and $\mathrm{SO}-\mathrm{PEG}-\mathrm{PLGA}-\mathrm{Fe}_{3} \mathrm{O}_{4}$ ) and SO, PEG and SO+PEG mixture in human lung cells after $4 \mathrm{~h}$ and $24 \mathrm{~h}$ treatment determined by MTT, LDH and Trypan blue exclusion test (TB).

\begin{tabular}{|c|c|c|c|c|c|}
\hline \multirow[b]{2}{*}{ Agent } & \multirow[b]{2}{*}{ Assay } & \multicolumn{2}{|c|}{ A549 } & \multicolumn{2}{|c|}{ HEL 12469} \\
\hline & & $4 \mathrm{~h}$ & $24 \mathrm{~h}$ & $4 \mathrm{~h}$ & $24 \mathrm{~h}$ \\
\hline \multirow{3}{*}{$\begin{array}{l}\mathbf{S O}_{-\mathrm{Fe}_{3}} \mathbf{O}_{4} \\
{[\mathrm{mM}]}\end{array}$} & MTT & 5.726 & 0.759 & 0.820 & 0.414 \\
\hline & $\mathrm{TB}$ & 1.321 & 1.009 & - & - \\
\hline & $\mathrm{LDH}$ & nd & nd & - & - \\
\hline \multirow{3}{*}{$\begin{array}{l}\text { SO-PEG-Fe } \mathbf{O}_{3} \\
{[\mathrm{mM}]}\end{array}$} & MTT & 1.183 & 0.344 & 0.593 & 0.311 \\
\hline & $\mathrm{TB}$ & 0.933 & 0.457 & - & - \\
\hline & $\mathrm{LDH}$ & nd & nd & & - \\
\hline \multirow{3}{*}{$\begin{array}{l}\text { SO-PEG-PLGA-Fe } \mathbf{O}_{4} \\
{[\mathrm{mM}]}\end{array}$} & MTT & 1.611 & 0.184 & 0.282 & 0.129 \\
\hline & $\mathrm{TB}$ & - & - & - & - \\
\hline & LDH & nd & nd & - & - \\
\hline SO & MTT & 0.725 & 0.263 & - & - \\
\hline \multirow[t]{2}{*}[\mathrm{mM}]{} & $\mathrm{TB}$ & 0.415 & 0.342 & - & - \\
\hline & LDH & 0.927 & 0.209 & - & - \\
\hline PEG & MTT & $>0.125$ & $>0.125$ & - & - \\
\hline \multirow[t]{2}{*}[\mathrm{mM}]{} & $\mathrm{TB}$ & $>0.125$ & $>0.125$ & - & - \\
\hline & LDH & $>0.125$ & $>0.125$ & - & - \\
\hline SO+PEG & MTT & 0.679 & 0.192 & - & - \\
\hline \multirow[t]{2}{*}[\mathrm{mM}]{$^{\mathrm{a}}$} & $\mathrm{TB}$ & - & - & - & - \\
\hline & LDH & 1.127 & 0.253 & - & - \\
\hline
\end{tabular}

${ }^{a}$ the ratio SO:PEG in the mixture was 14:1 as in the stock solution of magnetic fluid (SO-PEG- $\mathrm{Fe}_{3} \mathrm{O}_{4}$ )

nd - not determined due to interference of the color of the magnetic fluid with the spectrophotometry readings 

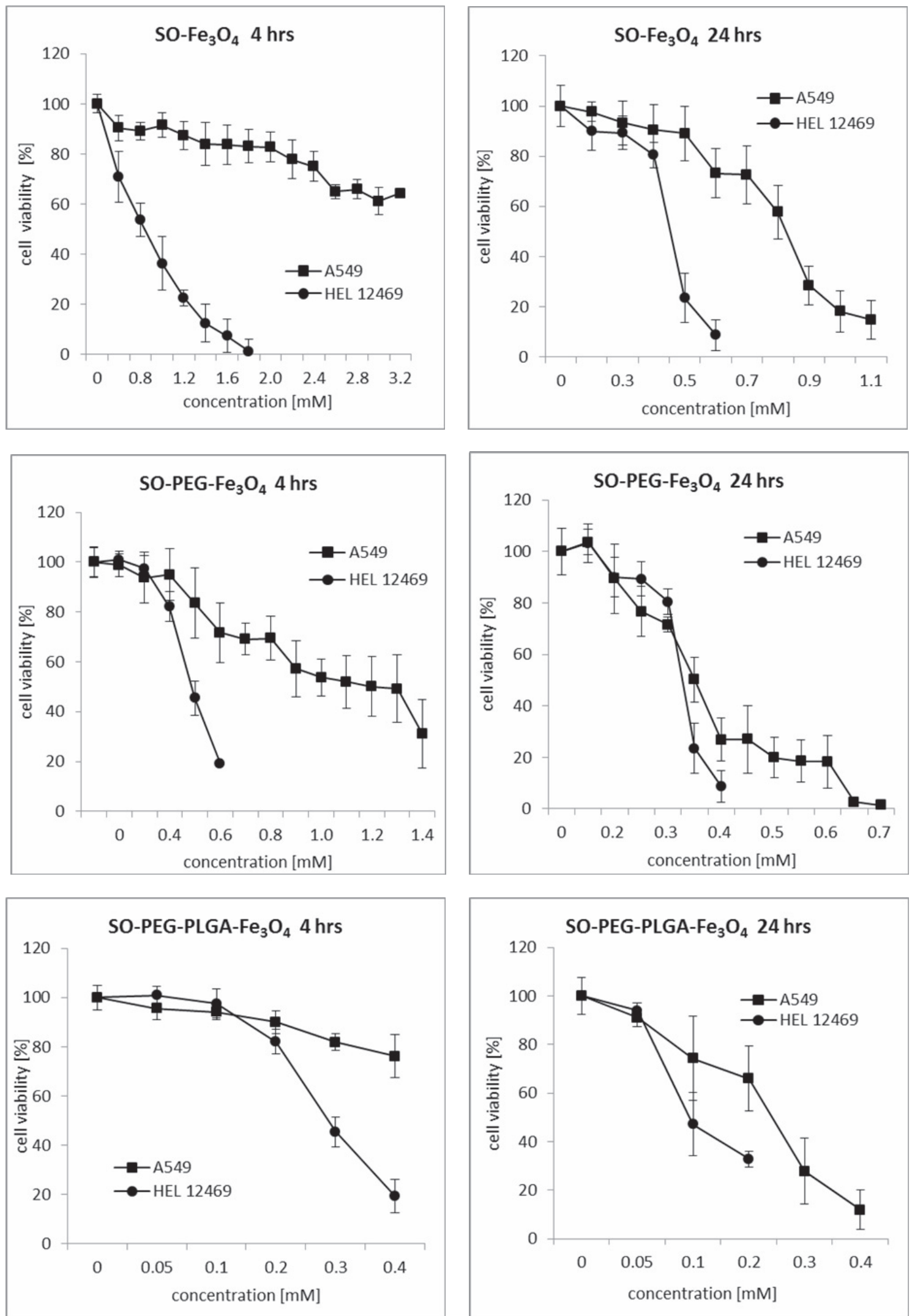

Figure 7. Cytotoxicity of $\mathrm{SO}-\mathrm{Fe}_{3} \mathrm{O}_{4}, \mathrm{SO}-\mathrm{PEG}-\mathrm{Fe}_{3} \mathrm{O}_{4}$ and SO-PEG-PLGA-Fe $\mathrm{O}_{4}$ particles in A549 and HEL 12469 cells after $4 \mathrm{~h}$ and $24 \mathrm{~h}$ treatment. 
trypan blue exclusion test were used to evaluate the cytotoxicity of MNPs with different surface modifications in human lung cells to avoid false positive results (Table 2). Based on the preliminary experiments, LDH assay was shown to be unusable for measurement of MNPs cytotoxicity because bulk of the MNPs remained in the culture medium after centrifugation and interfered with the spectrophotometry readings. This method was therefore excluded from the battery of cytotoxicity detection techniques dealing with MNPs cytotoxicity. Concerning the trypan blue exclusion assay, the addition of trypan blue stain directly to culture medium with MNPs resulted in difficulty to discriminate between the blue cells and clear cells and therefore embarrassed the analysis. Although interference between the color of MNPs and reagent also appeared in the MTT assay, modifications introduced in this method allowed us to assess MNPs cytotoxicity in both A549 and HEL12469 cells.

The cytotoxicity of magnetic fluids was measured in concentration range $0-3.2 \mathrm{mM}$ after short-term $(4 \mathrm{~h})$ and long-term ( $24 \mathrm{~h}$ ) cell exposure (Fig. 7). All MNPs induced a dose- and timedependent increase of cytotoxicity in both cell lines. In general, HEL 12469 cells were more sensitive to MNPs exposure than A549 cells. Substantially higher $\mathrm{IC}_{50}$ values calculated from the dose-response curves were determined for A549 cells mainly after short-term exposure than for HEL 12469 cells (Table 2). Since the surface area of the particles increased proportionally with the particle coating, the surface area of SO-PEG-PLGA$\mathrm{Fe}_{3} \mathrm{O}_{4}$ nanoparticles at equal number of particles was nearly 12 -fold larger than that of $\mathrm{SO}-\mathrm{Fe}_{3} \mathrm{O}_{4}$ ones. If we equalized the doses based on surface area to all MNPs, then $0.2 \mathrm{mM} \mathrm{SO}-\mathrm{Fe}_{3} \mathrm{O}_{4}$ $\left(2364.7 \mathrm{~cm}^{2}\right)$ correspond to $67 \mu \mathrm{M} \mathrm{SO}-\mathrm{PEG}-\mathrm{Fe}_{3} \mathrm{O}_{4}$, and $16 \mu \mathrm{M}$ concentration of SO-PEG-PLGA-Fe $\mathrm{O}_{4}$ particles and the cytotoxicity of all three MNPs is very similar.

Since MNPs clearance was a slow process, the viability of each lung cell line was evaluated also after post-cultivation of cells in fresh medium, $24 \mathrm{~h}$ and $48 \mathrm{~h}$ after the treatment. In general, post-cultivation of treated cells in fresh medium did not result in cell survival recovery, on the contrary, the vitality of exposed cells decreased progressively (Fig. 8). In order to better compare the "late" cytotoxicity of individual surfacecoated MNPs, the cell viability of A549 and HEL 12469 cells was expressed as the ratio of the cell viability at $24 \mathrm{~h}$ and 48 $\mathrm{h}$ time intervals (\%) to the cell survival of particular treated cells determined immediately after exposure (100\%). The equimolar concentrations, $0.4 \mathrm{mM}$ for $\mathrm{SO}-\mathrm{Fe}_{3} \mathrm{O}_{4}$ and SO-PEG$\mathrm{Fe}_{3} \mathrm{O}_{4}$ and $0.2 \mathrm{mM}$ for SO-PEG-PLGA-Fe $\mathrm{O}_{4}$ particles (because of the stronger cytotoxicity), were used to compare the late cytotoxicity of MNPs. Consistent with the acute cytotoxicity data, the viability of HEL 12469 cells decreased more dramatically than that of A549 cells. Moreover, SO-PEG-PLGA-Fe $\mathrm{O}_{4}$ particles were again the most cytotoxic particles for both A549 and HEL 12469 cells.

The cytotoxicity of SO per se and PEG alone, as well as their mixture, SO+PEG, was also evaluated (Table 2). A doseand time-dependent decrease in cell viability was found after exposure to $\mathrm{SO}$ alone or SO+PEG mixture; however,
A

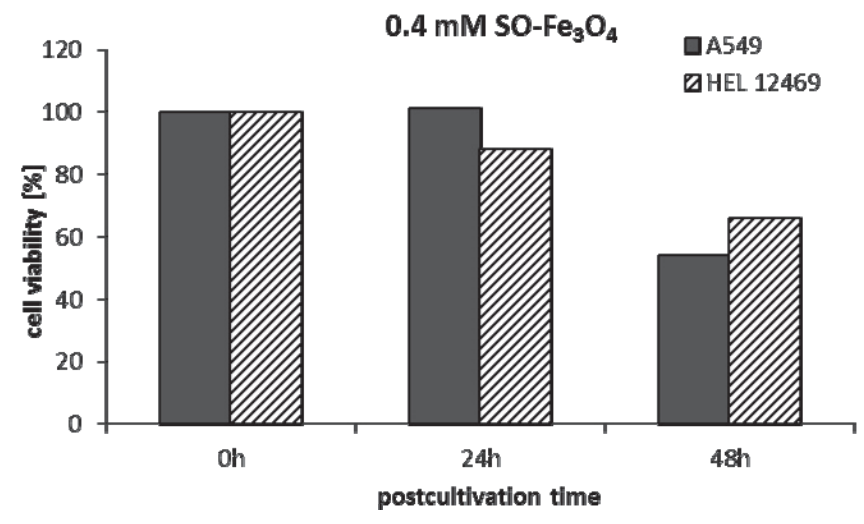

B

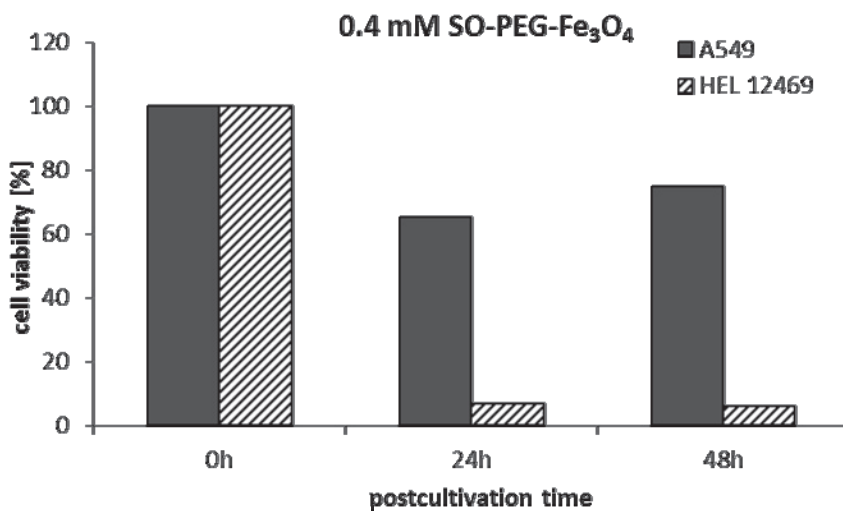

C

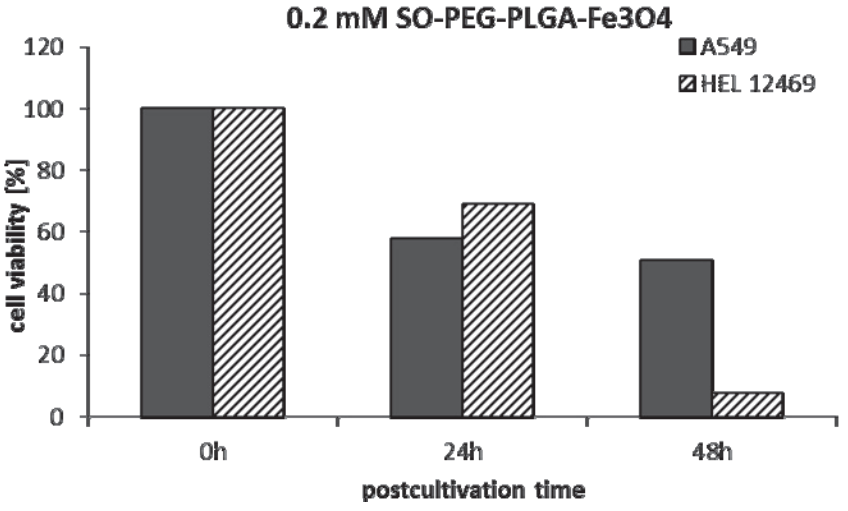

Figure 8. Cytotoxicity of magnetic fluids and nanospheres in human pulmonary cells at $24 \mathrm{~h}$ and $48 \mathrm{~h}$ after treatment. A549 cells and HEL 12469 cells were exposed to $0.4 \mathrm{mM} \mathrm{SO}-\mathrm{Fe}_{3} \mathrm{O}_{4}(\mathrm{~A}), 0.4 \mathrm{mM}$ SO-PEG-Fe $\mathrm{O}_{4}(\mathrm{~B})$ and $0.2 \mathrm{mM}$ SO-PEG-PLGA-Fe $\mathrm{O}_{4}(\mathrm{C})$ for $24 \mathrm{~h}$. The cell viability represent relative values and is expressed as the ratio of cell viability at $24 \mathrm{~h}$ and $48 \mathrm{~h}$ time intervals (\%) to the cell survival of particular treated cells determined immediately after exposure (100\%).

no cytotoxicity was detected in PEG-treated lung cells. Cytotoxicity of the surfactant $\mathrm{SO}$ and the mixture of SO+PEG was even stronger than the cytotoxicity of $\mathrm{SO}-\mathrm{Fe}_{3} \mathrm{O}_{4}$ and 
A

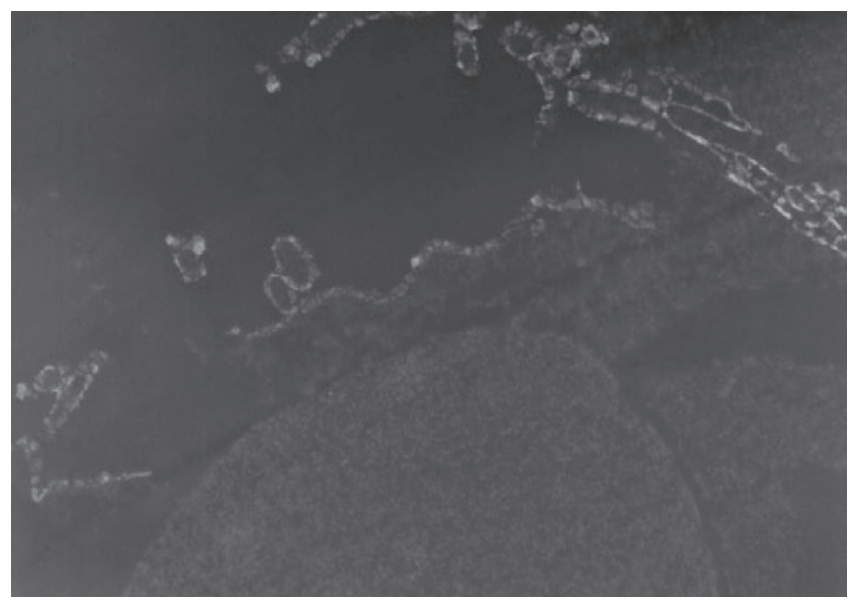

B

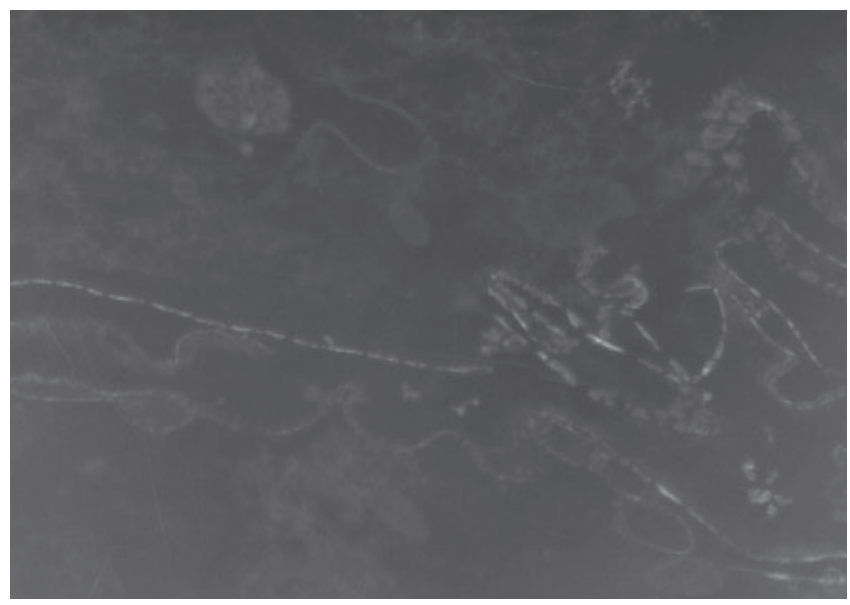

Figure 9. Ultrastructure of A549 (A) and HEL 12469 (B) cell surface determined by ruthenium red staining. Differences between A549 and HEL 12469 cells in the thickness of the mucopolysaccharide-rich coat layer deposited at the cell surfaces. Magn. $10000 \mathrm{x}$.

SO-PEG- $\mathrm{Fe}_{3} \mathrm{O}_{4}$ when equimolar concentrations were used. These results indicated that the behavior of free surfactant/ polymer or their mixtures differed from that of immobilized surfactant/polymer on MNPs. Oleic acids at low concentrations were shown to pass through the membrane because of their very similar structure as lipid [27]; however, at higher concentrations, the critical micelle concentrations (CMC), oleic acids can form aggregates and decreased substantially the cell viability [28]. Based on these preliminary results the toxicity of PLGA and their mixture (SO+PEG+PLGA) was not evaluated in this study.

Ultrastructure of A549 and HEL 12469 cell surface. In order to explain the differences between human lung tumor cells and human lung diploid cells in the intensity of cellular uptake of coated MNPs, the ultrastrucure of A549 and HEL 12469 cell surfaces was analyzed using ruthenium red staining.
Ruthenium red reacts with the acid mucopolysaccharides and the acid glycosaminoglycans that are constantly associated with membrane proteins [29]. Differences between human lung tumor cells and human lung diploid cells were found in the thickness of the mucopolysaccharide-rich coat layer deposited at the cell surfaces of the particular cell line (Fig. 9). The ruthenium red layer observed in HEL 12469 cells (Fig. 9B) was approximately 3.1-5 nm thick while nearly two-fold increased thickness and more irregular ruthenium red layer was observed in A549 (5-7.1 nm) (Fig. 9A).

\section{Discussion}

The detailed physicochemical characterization of nanoparticles as well as the control of particle interactions with biological fluids and media is essential for reliable studies aimed at the intensity of internalization and biological activity of nanoparticles both in vivo and in vitro. In our study, we prepared magnetic nanoparticles of size $7.6 \mathrm{~nm}$ with magnetite inner core and hydrophilic outer shell of surfactant and polymers which are widely used in biomedical research. Prepared nanocolloid magnetic fluids showed very high stability at neutral $\mathrm{pH}$ with no sedimentation observed even after several weeks of storage at room temperature. TEM results revealed that serum in the culture medium contributed substantially to particle dispersion and allowed particles to enter the human lung cells. In serum-free medium, MNPs underwent rapid aggregation apparently because of a high ionic strength of culture medium [30] and no MNPs were found inside the cells. A rapid agglomeration of polyvinyl alcohol/vinyl amine coated magnetite nanoparticles in serum-free medium have reported also Petri-Fink et al. [31]. Plasma proteins have been shown to compete for the nanoparticle surface, leading to a protein "corona" when particles enter a biological fluid or culture media $[32,33]$. FTIR spectra revealed the immobilization of serum protein(s) on MNPs surface. Moreover, differences in the intensity of serum protein binding on the particle surface in dependence on serum concentration in culture medium correlated with TEM results. Less efficient MNPs uptake was observed at $10 \%$ FCS than at $2 \%$ FCS in culture medium. In line with our results, a larger amount of maghemite nanoparticles has been observed inside HeLa cells at 1\% FCS than at 10\% FCS in culture medium [34]. These data indicated that MNPs internalization might affect also the ratio between the serum proteins and the amount of nanoparticles. The protein corona has been shown to be a dynamic structure, largely determined by the extracellular milieu $[35,36]$, and substantially influences dispersion, biodistribution, mechanism of internalization and biological activity of nanoparticles [33, 37]. Albumin, fibrinogen and immunoglobulins (Ig) have been shown to be the principal plasma proteins that bind to iron oxide nanoparticles when they come in contact with plasma [38]. We suppose that MNPs internalization into human lung cells might be mediated via IgG since negatively charged particles have been shown to predominantly bound proteins with isolectric points greater 
than 5.5 such as IgG [39]. Further study is, however, required to verify this hypothesis.

MNPs uptake is an active energy-dependent process; incubation of the human lung cells at $4^{\circ} \mathrm{C}$ prior to MNPs treatment resulted in restriction of MNPs internalization. Suppression of MNPs uptake into A549 cell at low temperature has observed also Kim et al. [7]. It is supposed that the particle size determines the mechanism of nanoparticle entrance into cells [40]. However, the data published so far lack concordance about the threshold diameter which determines the particular endocytotic pathway involved in particle internalization [41]. Using the specific metabolic inhibitors it has been shown that magnetite nanoparticles of the hydrodynamic size around 80 $\mathrm{nm}$ are internalized by clathrin-mediated endocytosis [7, 42]. Further experiments are required to determine the precise mechanism(s) of cellular uptake of particular coated MNPs used in this study.

Substantial differences between the human lung tumor cells and the human lung diploid cells have been found concerning the uptake amount of coated MNPs and MNPs cytotoxicity. Only limited number of studies has been performed so far dealing with the intensity of internalization and cytotoxicity of surface modified nanoparticles in tumor cells and their non-tumor (healthy) counterparts. Vast majority of existing studies were carried out using either various human tumor cell lines or mouse and rat cells [43-45]. In addition, experiments performed on human non-tumor cells are also scarce [26]. Surprisingly, substantially lower internalized amount of MNPs were detected in A549 cells compared with HEL 12469. In contrast, a preferential uptake of the aminosilane-coated $\mathrm{Fe}_{3} \mathrm{O}_{4}$ nanoparticles into human lung tumor SPC-A1 cells compared with non-tumor lung WI-38 cells [46] and human prostate cancer cells $v s$. human non-tumor prostate cells [2] has been reported. The internalized amount of MNPs in human lung SPC-A1 was substantially larger (202 pg Fe/cell) than that determined in A549 cells ( $0.1-0.5 \mathrm{pg} \mathrm{Fe} / \mathrm{cell})$ though comparable internalized amount of MNPs was determined in human lung non-tumor WI-38 cells and HEL 12469 cells (13 pg Fe/cell and $2.2-9.7 \mathrm{pg} \mathrm{Fe} /$ cell, respectively). Several studies convincingly demonstrated that particle uptake may differ among different cell types. The mouse macrophages (RAW 264.7) were for example shown to internalized PEGmodified MNPs less efficiently than the human breast cancer cells [9]. Recent study has revealed that the human alveolar type 2 cells internalized nanoparticles less efficiently than the human alveolar type 1 cells [47]. Since A549 cells are representatives of the alveolar epithelial type 2-like cells [15] it is reasonable to suppose that this fact might underlie less efficient MNPs entrance into the human lung tumor cells compared with the human lung diploid cells. Moreover, Ge et al. [44] have reported recently that positively charged magnetite nanoparticles are more efficiently taken up into KB cells due to electrostatic attraction to the negatively charged cell membrane than negatively charged particles. In contrast, a preferential uptake of negatively charged particles into im- mortalized alveolar epithelial type 1 cells has been found [47]. Surface charge as an important parameter in biological activity of nanoparticles has been supported also by other authors [12, 48-51]. However, a mechanical hindrance of MNPs uptake cannot be excluded. Nearly two-fold increased thickness of the mucopolysaccharide-rich coat layer deposited at the cell surfaces of A549 cells compared with HEL 12469 cells was determined by ruthenium red staining. We could speculate that the cell surface ultrastructure might also contribute to a less efficient MNPs uptake into lung tumor cells.

An association between the uptake amount of MNPs and the cell viability was found. Consistent with AAS results, the coated MNPs decreased the cell survival of HEL 12469 cells more dramatically than A549 cells, mainly after 4 h treatment. SO- $\mathrm{Fe}_{3} \mathrm{O}_{4}$ particles with the smallest hydrodynamic size $(44 \mathrm{~nm})$ were at least two-fold less cytotoxic than the larger particles, SO-PEG- $\mathrm{Fe}_{3} \mathrm{O}_{4}$ and SO-PEG-PLGA-Fe $\mathrm{O}_{4}$ $\left(\mathrm{D}_{\mathrm{H}}=76 \mathrm{~nm}\right.$ and $155 \mathrm{~nm}$, respectively). Our data are consistent with results of Ying and Hwang [52] and Yin et al. [28] who reported a size-dependent cytotoxicity of iron oxide and nickel ferrite nanoparticles. The authors hypothesize that larger particles possess larger effective interaction area with more functional groups for accessing to the cell in comparison with smaller particles [28]. Based on our results we suppose that the particle size area rather than the surface modifications determined MNPs cytotoxicity. Our results might be of biomedical relevance in such cases where MNPs should be used as nanocarriers for targeted delivery of drugs into tumors derived from alveolar epithelial cells.

Acknowledgements: The authors express their appreciation to Dr. Jan Topinka, D.Sc., Department of Genetic Ecotoxicology, Institute of Experimental Medicine, AS CR, Prague, Czech Republic, who kindly offered human diploid HEL 12469 cells and Dr. Miroslav Machala, Ph.D., Veterinary Research Institute, Brno, Czech Republic, for providing us with human lung tumor cells A549. The authors wish to thank Tomas Krivulcik, Ph.D. and Mrs. Alzbeta Vokalikova for excellent technical assistance. This study was supported by the VEGA grant 2/0051/09, and by the grant through the EEA FM and the NFM (project SK0020).

\section{References}

[1] SINGH N, MANSHIAN B, JENKINS GJ, GRIFFITHS SM, WILLIAMS PM et al. NanoGenotoxicology: the DNA damaging potential of engineered nanomaterials. Biomaterials 2009; 30: 3891-3914. http://dx.doi.org/10.1016/j.biomaterials.2009 .04 .009

[2] JORDAN A, SCHLOZ R, MAIER-HAUFF K, JOHANNSEN $M$, WUST $P$ et al. Presentation of a new magnetic field therapy system for the treatment of human solid tumors with magnetic fluid hyperthermia. J Magn Magn Mater 2001; 225: 118-126. http://dx.doi.org/10.1016/S0304-8853(00)01239-7

[3] TORCHILIN VP. Drug targeting. Eur J Pharm Sci 2000; 11 Suppl 2: S81-S91. http://dx.doi.org/10.1016/S09280987(00)00166-4 
[4] XIANG JJ, TANG JQ, ZHU SG, NIE XM, LU HB et al. IONPPLL: a novel non-viral vector for efficient gene delivery. J Gene Med 2003; 5: 803-817. http://dx.doi.org/10.1002/jgm.419

[5] LUBBE AS, BERGEMANN C, RIESS H, SCHRIEVER F, REICHARDT $P$ et al. Clinical experiences with magnetic drug targeting: a phase I study with 4'-epidoxorubicin in 14 patients with advanced solid tumors. Cancer Res 10-15-1996; 56: 4686-4693.

[6] MARSZALL MP. Application of magnetic nanoparticles in pharmaceutical sciences. Pharm Res 2011; 28: 480-483. http://dx.doi.org/10.1007/s11095-010-0284-6

[7] KIM JS, YOON TJ, YU KN, NOH MS, WOO M et al. Cellular uptake of magnetic nanoparticle is mediated through energy-dependent endocytosis in A549 cells. J Vet Sci 2006; 7: 321-326. http://dx.doi.org/10.4142/jvs.2006.7.4.321

[8] GUPTA AK, GUPTA M. Synthesis and surface engineering of iron oxide nanoparticles for biomedical applications. Biomaterials 2005; 26: 3995-4021. http://dx.doi.org/10.1016/ j.biomaterials.2004.10.012

[9] ZHANG Y, KOHLER N, ZHANG M. Surface modification of superparamagnetic magnetite nanoparticles and their intracellular uptake. Biomaterials 2002; 23: 1553-1561. http://dx.doi. org/10.1016/S0142-9612(01)00267-8

[10] BABIC M, HORAK D, TRCHOVA M, JENDELOVA P, GLOGAROVA K et al. Poly(l-lysine)-Modified Iron Oxide Nanoparticles for Stem Cell Labeling. Bioconjug Chem 2-212008; 19: 740-750.

[11] KEMENY NE, NIEDZWIECKI D, HOLLIS DR, LENZ HJ, WARREN RS et al. Hepatic arterial infusion versus systemic therapy for hepatic metastases from colorectal cancer: a randomized trial of efficacy, quality of life, and molecular markers (CALGB 9481). J Clin Oncol 2006; 24: 1395-1403. http://dx.doi.org/10.1200/JCO.2005.03.8166

[12] SALOMON JJ, EHRHARDT C. Nanoparticles attenuate P-glycoprotein/MDR1 function in A549 human alveolar epithelial cells. Eur J Pharm Biopharm 2011; 77: 392-397. http://dx.doi.org/10.1016/j.ejpb.2010.11.009

[13] GUERIN C, OLIVI A, WEINGART JD, LAWSON HC, BREM H. Recent advances in brain tumor therapy: local intracerebral drug delivery by polymers. Invest New Drugs 2004; 22: 27-37. http://dx.doi.org/10.1023/B: DRUG.0000006172.65135.3e

[14] GAGNADOUX F, HUREAUX J, VECELLIO L, URBAN T, LE PAPE A et al. Aerosolized chemotherapy. J Aerosol Med Pulm Drug Deliv 2008; 21: 61-70. http://dx.doi.org/10.1089/ jamp.2007.0656

[15] FOSTER KA, OSTER CG, MAYER MM, AVERY ML, AUDUS KL. Characterization of the A549 cell line as a type II pulmonary epithelial cell model for drug metabolism. Exp Cell Res 1998; 243: 359-366. http://dx.doi.org/10.1006/ excr.1998.4172

[16] SPORTY JL, HORALKOVA L, EHRHARDT C. In vitro cell culture models for the assessment of pulmonary drug disposition. Expert Opin Drug Metab Toxicol 2008; 4: 333-345. http://dx.doi.org/10.1517/17425255.4.4.333

[17] MANSOUR HM, RHEE YS, WU X. Nanomedicine in pulmonary delivery. Int J Nanomedicine 2009; 4: 299-319.
[18] BORM PJ, ROBBINS D, HAUBOLD S, KUHLBUSCH T, FISSAN $\mathrm{H}$ et al. The potential risks of nanomaterials: a review carried out for ECETOC. Part Fibre Toxicol 2006; 3: 11. http:// dx.doi.org/10.1186/1743-8977-3-11

[19] BECK-BROICHSITTER M, SCHWEIGER C, SCHMEHL T, GESSLER T, SEEGER W et al. Characterization of novel spray-dried polymeric particles for controlled pulmonary drug delivery. J Control Release 2011.

[20] CARVALHO TC, CARVALHO SR, MCCONVILLE JT. Formulations for pulmonary administration of anticancer agents to treat lung malignancies. J Aerosol Med Pulm Drug Deliv 2011; 24: 61-80. http://dx.doi.org/10.1089/jamp.2009.0794

[21] ZAVISOVA V, KONERACKA M, STRBAK O, TOMASOVICOVA N, KOPCANSKY P et al. Encapsulation of indomethacin in magnetic biodegradable polymer nanoparticles. J Mag Mag Mater 2007; 311: 379-382. http://dx.doi. org/10.1016/j.jmmm.2006.11.177

[22] ZAVISOVA V, KONERACKA M, MUCKOVA M, LAZOVA J, JURIKOVA A et al. Magnetic fluid poly(ethylene glycol) with moderate anticancer activity. J Mag Mag Mater 2011; 323: 1408-1412. http://dx.doi.org/10.1016/ j.jmmm.2010.11.060

[23] FESSI H, PUISIEUX F, DEVISSAGUET JP, AMMOURY N, BENITA S. Nanocapsules formation by interfacial deposition following solvent displacement. Int J Pharm 1989; 55: R1-R4. http://dx.doi.org/10.1016/0378-5173(89)90281-0

[24] KONERACKA M, MUCKOVA M, ZAVISOVA V, TOMASOVICOVA N, KOPCANSKY P et al. Encapsulation of anticancer drug and magnetic particles in biodegradable polymer nanospheres. J Phys Condens Matter 2008; 20: 204151. http://dx.doi.org/10.1088/0953-8984/20/20/ $\underline{204151}$

[25] MOSMANN T. Rapid colorimetric assay for cellular growth and survival: application to proliferation and cytotoxicity assays. J Immunol Methods 1983; 65: 55-63. http://dx.doi. org/10.1016/0022-1759(83)90303-4

[26] HAFELI UO, RIFFLE JS, HARRIS-SHEKHAWAT L, CARMICHAEL-BARANAUSKAS A, MARK F et al. Cell uptake and in vitro toxicity of magnetic nanoparticles suitable for drug delivery. Mol Pharm 2009; 6: 1417-1428. http://dx.doi. org/10.1021/mp900083m

[27] HAMILTON JA, GUO W, KAMP F. Mechanism of cellular uptake of long-chain fatty acids: Do we need cellular proteins? Mol Cell Biochem 2002; 239: 17-23. http://dx.doi.org/10.1023/ A:1020542220599

[28] YIN H, TOO HP, CHOW GM. The effects of particle size and surface coating on the cytotoxicity of nickel ferrite. Biomaterials 2005; 26: 5818-5826. http://dx.doi.org/10.1016/ j.biomaterials.2005.02.036

[29] MARTINEZ-PALOMO A, BRAISLOVSKY C, BERNHARD W. Ultrastructural modifications of the cell surface and intercellular contacts of some transformed cell strains. Cancer Res 1969; 29: 925-937.

[30] LANDSIEDEL R, MA-HOCK L, KROLL A, HAHN D, SCHNEKENBURGER J et al. Testing metal-oxide nanomaterials for human safety. Adv Mater 2010; 22: 2601-2627. http://dx.doi.org/10.1002/adma.200902658 
[31] PETRI-FINK A, STEITZ B, FINKA A, SALAKLANG J, HOFMANN H. Effect of cell media on polymer coated superparamagnetic iron oxide nanoparticles (SPIONs): colloidal stability, cytotoxicity, and cellular uptake studies. Eur J Pharm Biopharm 2008; 68: 129-137. http://dx.doi.org/10.1016/ j.ejpb.2007.02.024

[32] RUH H, KUHL B, BRENNER-WEISS G, HOPF C, DIABATE $S$ et al. Identification of serum proteins bound to industrial nanomaterials. Toxicol Lett 2012; 208: 41-50. http://dx.doi. org/10.1016/j.toxlet.2011.09.009

[33] AGGARWAL P, HALL JB, MCLELAND CB, DOBROVOLSKAIA MA, MCNEIL SE. Nanoparticle interaction with plasma proteins as it relates to particle biodistribution, biocompatibility and therapeutic efficacy. Adv Drug Deliv Rev 2009; 61: 428-437. http://dx.doi.org/10.1016/j.addr.2009.03.009

[34] SINGH N, JENKINS GJ, NELSON BC, MARQUIS BJ, MAFFEIS TG et al. The role of iron redox state in the genotoxicity of ultrafine superparamagnetic iron oxide nanoparticles. Biomaterials 2012; 33: 163-170. http://dx.doi.org/10.1016/ j.biomaterials.2011.09.087

[35] LYNCH I, CEDERVALL T, LUNDQVIST M, CABALEIRO-LAGO C, LINSE $S$ et al. The nanoparticle-protein complex as a biological entity; a complex fluids and surface science challenge for the 21 st century. Adv Colloid Interface Sci 2007; 134-135: 167-174. http://dx.doi.org/ 10.1016/j.cis.2007.04.021

[36] CEDERVALL T, LYNCH I, LINDMAN S, BERGGARD T, THULIN E et al. Understanding the nanoparticle-protein corona using methods to quantify exchange rates and affinities of proteins for nanoparticles. Proc Natl Acad Sci USA 2007; 104 : 2050-2055. http://dx.doi.org/10.1073/pnas.0608582104

[37] DUTTA D, SUNDARAM SK, TEEGUARDEN JG, RILEY BJ, FIFIELD LS et al. Adsorbed proteins influence the biological activity and molecular targeting of nanomaterials. Toxicol Sci 2007; 100: 303-315. http://dx.doi.org/10.1093/toxsci/ $\mathrm{kfm} 217$

[38] THODE K, LUCK M, SEMMLER W, MULLER RH, KRESSE M. Determination of plasma protein adsorption on magnetic iron oxides: sample preparation. Pharm Res 1997; 14: 905-910. http://dx.doi.org/10.1023/A:1012104017761

[39] GESSNER A, LIESKE A, PAULKE BR, MULLER RH. Functional groups on polystyrene model nanoparticles: influence on protein adsorption. J Biomed Mater Res A 2003; 65: 319-326. http://dx.doi.org/10.1002/jbm.a.10371

[40] PETROS RA, DESIMONE JM. Strategies in the design of nanoparticles for therapeutic applications. Nat Rev Drug Discov 2010; 9: 615-627. http://dx.doi.org/10.1038/nrd2591

[41] MARANO F, HUSSAIN S, RODRIGUES-LIMA F, BAEZASQUIBAN A, BOLAND S. Nanoparticles: molecular targets and cell signalling. Arch Toxicol 2011; 85: 733-741. http:// dx.doi.org/10.1007/s00204-010-0546-4

[42] YANG CY, TAI MF, LIN CP, LU CW, WANG JL et al. Mechanism of cellular uptake and impact of ferucarbotran on macrophage physiology. PLoS One 2011; 6: e25524. http:// dx.doi.org/10.1371/journal.pone.0025524

[43] CHOI JY, LEE SH, NA HB, AN K, HYEON T et al. In vitro cytotoxicity screening of water-dispersible metal oxide nanoparticles in human cell lines. Bioprocess Biosyst Eng 2010; 33: 21-30. http://dx.doi.org/10.1007/s00449-009-0354-5

[44] GE Y, ZHANG Y, XIA J, MA M, HE S et al. Effect of surface charge and agglomerate degree of magnetic iron oxide nanoparticles on KB cellular uptake in vitro. Colloids Surf B Biointerfaces 2009; 73: 294-301. http://dx.doi.org/10.1016/ j.colsurfb.2009.05.031

[45] LEWINSKI N, COLVIN V, DREZEK R. Cytotoxicity of nanoparticles. Small 2008; 4: 26-49. http://dx.doi.org/10.1002/ $\underline{\text { smll.200700595 }}$

[46] MA YJ, GU HC. Study on the endocytosis and the internalization mechanism of aminosilane-coated $\mathrm{Fe} 3 \mathrm{O} 4$ nanoparticles in vitro. J Mater Sci Mater Med 2007; 18: 2145-2149. http:// dx.doi.org/10.1007/s10856-007-3015-8

[47] KEMP SJ, THORLEY AJ, GORELIK J, SECKL MJ, O'HARE $\mathrm{MJ}$ et al. Immortalization of human alveolar epithelial cells to investigate nanoparticle uptake. Am J Respir Cell Mol Biol 2008; 39: 591-597. http://dx.doi.org/10.1165/rcmb.2007-0334OC

[48] NGUYEN J, REUL R, BETZ T, DAYYOUB E, SCHMEHL $T$ et al. Nanocomposites of lung surfactant and biodegradable cationic nanoparticles improve transfection efficiency to lung cells. J Control Release 2009; 140: 47-54. http://dx.doi. org/10.1016/j.jconrel.2009.07.017

[49] ORR G, PANTHER DJ, PHILLIPS JL, TARASEVICH BJ, DOHNALKOVA A et al. Submicrometer and nanoscale inorganic particles exploit the actin machinery to be propelled along microvilli-like structures into alveolar cells. ACS Nano 2007; 1: 463-475. http://dx.doi.org/10.1021/nn700149r

[50] PERUMAL OP, INAPAGOLLA R, KANNAN S, KANNAN RM. The effect of surface functionality on cellular trafficking of dendrimers. Biomaterials 2008; 29: 3469-3476.

[51] HARUSH-FRENKEL O, BIVAS-BENITA M, NASSAR T, SPRINGER C, SHERMAN Y et al. A safety and tolerability study of differently-charged nanoparticles for local pulmonary drug delivery. Toxicol Appl Pharmacol 2010; 246: 83-90. http://dx.doi.org/10.1016/j.taap.2010.04.011

[52] YING E, HWANG H-M. In vitro evaluation of the cytotoxicity of iron oxide nanoaprticles with different coatings and different sizes in A3 human T lymphocytes. Science Of The Total Environment 2010; 408: 4475-4481. http://dx.doi. org/10.1016/j.scitotenv.2010.07.025 